\title{
INTERAKSI ISLAM DAN BUDAYA LOKAL DALAM TRADISI SYUKURAN LAUT DI KUALA JELAI KALIMANTAN TENGAH
}

\author{
Alimaturraiyah*, Zaenuddin Hudi Prasojo** \\ alimaturraiyah221995@gmail.com*,zaestain@yahoo.com**
}

IAIN Pontianak

\begin{abstract}
Every society has a culture that comes in various forms. One form of culture that can be found in our lives is the local culture. The Kuala Jelai community has local wisdom, which is an appreciation of the sea with the concept of sea thanksgiving. Local wisdom of a community is beneficial for other communities because the value of local wisdom is undoubtedly something that has been tested by time and space. This article is intended to elaborate on the tradition of sea Thanksgiving in Kuala Jelai, especially on the side of its preservation. Among the essential reasons for the tradition of sea thanksgiving is the role of the sea, which significantly helps the life of fishers, so that the people of Kuala Jelai held a thanksgiving sea as gratitude to God who has provided sustenance and safety for the fishermen and the surrounding community. In the process of implementing the sea thanksgiving tradition, there are several values contained therein, namely social values, religious values, and educational values.
\end{abstract}

Keywords: Sea Thanksgiving, Local Wisdom

\section{A. PENDAHULUAN}

Indonesia merupakan negara kepulauan, yang terdiri dari berbagai suku bangsa yang berbeda-beda. Masingmasing suku bangsa memiliki keanekaragaman budaya, yang mempunyai ciri-ciri khusus di setiap daerah. Keanekaragaman masyarakat dan kebudayaan terjadi karena dipengaruhi adanya berbagai suku bangsa atau etnik, faktor geografis, kontak budaya dan perbedaan mata pencaharian. Manusia tidak lepas dari kebudayaan dalam kehidupan sehari-harinya. Antara manusia dan kebudayaan saling berhubungan. Kebudayaan diperoleh atau dipelajari dari tradisi masyarakat, termasuk pola-pola hidup mereka, cara berpikir, perbuatan, perasaan dan tingkah laku (Asmito, 2010:25). Budaya suatu bangsa memiliki kebijaksanaan yang unik yang dapat diartikan sebagai kebijaksanaan dalam budaya tradisional masyarakat. Kebijaksanaan dalam arti luas tidak hanya norma-norma dan nilai-nilai budaya, tetapi juga semua elemen ide, termasuk mereka yang memiliki implikasi untuk teknologi, dan estetika (Zaenuddin, 2017:199).

Kebudayaan masyarakat selalu berkembang dari waktu ke waktu, perkembangan kebudayaan menimbulkan terjadinya perubahan kebudayaan atau transformasi kebudayaan. Transformasi kebudayaan dapat dilihat sebagai perubahan pola tingkah laku yang langsung atau tidak langsung menjadi pengetahuan sekelompok orang yang menjadi anggota suatu masyarakat. Dan budaya juga menjadi faktor yang membuat sekelompok orang menjadi bersama-sama, memiliki pemahaman yang sama tentang siapa mereka, dari mana mereka berasal, apa yang membuat mereka menjadi seperti sekarang, 
pemahaman umum tentang apa yang akan mereka lakukan. Budaya ini termanifestasi dalam sistem nilai dan arti yang diekspresikan melalui bahasa, simbol, ritual, gestur, dan tradisi. Kearifan lokal merupakan sistem nilai, norma, dan tradisi yang dijadikan sebagai acuan bersama oleh suatu kelompok sosial dalam menjalin hubungan dengan Tuhan, alam, dan sesama manusia (Rasyidin, 2009:218221).

Kebudayaan merupakan ciri pribadi manusia didalamnya mengandung normanorma, tataran nilai-nilai yang dimiliki dan dihayati oleh masyarakat pendukungnya. Penghayatan pada kebudayaan dapat dilakukan melalui proses sosialisasi, dalam proses sosialisasi manusia sebagai makhluk individu mulai dari masa kecil hingga masa tuanya belajar pola-pola tindakan dalam hubungan pergaulan dengan individuindividu lain disekelilingnya, yang mempunyai beraneka ragam peranan sosial yang ada dalam kehidupan seharihari (Wiranata, 2011:95).

Setiap kebudayaan yang dimiliki manusia mempunyai tujuh unsur kebudayaan yaitu bahasa, sistem pengetahuan, organisasi sosial, sistem peralatan hidup dan teknologi, sistem mata pencaharian hidup, sistem religi dan sistem kesenian (Koentjaraningrat, 1985:5). Kebudayaan dapat menunjukan derajat dan tingkah laku peradaban manusia, kebudayaan juga dapat menunjukan ciri kepribadian manusia atau masyarakat pendukungnya.

Adapun yang dimaksud dengan tradisi merupakan suatu kebudayaan yang menjadi ciri lokalitas masyarakat Indonesia. Upacara tradisional merupakan bagian yang integral dari kebudayaan masyarakat pendukungnya dan kelestarian hidupnya dimungkinkan oleh fungsinya bagi kehidupan masyarakat pendukungnya. Penyelenggaraan upacara tradisional itu sangat penting artinya bagi pembinaan sosial budaya warga masyarakat yang bersangkutan. Upacara tradisional biasanya berbentuk religi yang merupakan salah satu bagian dari kebudayaan yang tumbuh dan berkembang dalam masyarakat (Widati, 2011:143).

Tradisi Syukuran Laut yang sering dilakukan masyarakat nelayan merupakan salah satu kebudayaan di Indonesia yang masih dipertahankan sampai sekarang. Tradisi Syukuran Laut ini salah satunya pada kampung nelayan Kabupaten Sukamara yang dilaksanakan setiap tahun. Hal inilah yang menyebabkan keunikan tersendiri, dimana dengan ruang yang terbatas tetapi masih bisa melaksanakan tradisi.

Di daerah Sukamara masih memelihara Tradisi Syukuran Laut (sedekah laut) yang dilaksanakan oleh masyarakat nelayan. Dalam penyelenggaraan Syukuran Laut terdapat perkembangan yaitu yang dahulu hanya upacara saja tetapi sekarang mempunyai perkembangan yang pesat yaitu adanya hiburan dan diikuti oleh masyarakat luar Kuala Jelai. Hal tersebut disebabkan karena adanya teknologi komunikasi dan informasi yang semakin modern, serta adanya aneka hiburan yang hadir pada saat menjelang Tradisi Syukuran laut. Dan dahulunya pun syukuran laut ini hanya dilaksanakan oleh orang-orang tertentu saja. Berbeda dengan sekarang ini syukuran laut sudah mulai berkembang dari sebelumnya.

Tradisi Syukuran laut mengalami perubahan sesuai dengan perkembangan pola pikir masyarakat, perubahan tradisi ini juga tidak terlepas dari perubahan kebudayaan. Masyarakat Kuala Jelai mulai menyadari bahwa tradisi Syukuran Laut mempunyai fungsi yang lebih luas. Maksud dan tujuan dari Syukuran Laut ini yaitu memohon pada Tuhan Yang Maha Esa agar para nelayan dianugerahi hasil yang laut melimpah pada tahun yang akan datang dan dihindarkan pula dari marabahaya selama melaut.

Syukuran Laut di adakan di tepi pantai yakni di pantai anugerah yang 
memang dari dulu pun sering dijadikan sebagai tempat untuk melaksanakan tradisi syukuran laut itu sendiri. Warga Kuala Jelai sangat antusias sekali dalam mengikuti tradisi syukuran laut yang sampai saat ini masih mereka lestarikan secara bersama-sama.Upacara Tradisi Syukuran Laut ini juga merupakan bagian dari tradisi turun-temurun yang selalu dilakukan dan dilestarikan oleh masyarakat khusunya pada masyarakat Jelai. Tradisi adalah warisan masa lalu yang terus dilestarikan hingga sekarang yang berupa nilai, norma sosial, pola kelakuan dan adat kebiasaan lain yang merupakan wujud dari aspek berbagai kehidupan (Bawani, 1993:24).

Dalam tradisi syukuran laut ini menghadirkan kembali suatu proses atau peristiwa yang pernah dilakukan dahulu oleh leluhur. Maka usaha serupa pun akan terjadi lagi, karena hadirnya prosesi syukuran laut di masyarakat nelayan telah lama dan menjadi bagian didalam kehidupannya. Simbol-simbol yang ada didalam prosesi ini dapat berubah namun fungsinya akan tetap sama. Tata cara tradisi tiap daerah juga berbeda-beda sesuai keyakinan yang dipercaya oleh para nelayan sekitar. Tetapi pada dasarnya tradisi ini mempunyai makna yang sama, yaitu persembahan kepada Sang Penguasa alam semesta.

Hal yang menarik dari syukuran laut ini adalah pada pelaksanaan atau prosesi dari syukuran laut itu sendiri. Berbeda dengan daerah lain yang mempunyai ritual dan prosesi sendiri dalam melakukan tradisi syukuran laut. Keberadaan Tradisi Syukuran Laut di Kabupaten Sukamara tersebut merupakan bagian dari sistem sosial yang keberadaannya sangat menarik untuk di dekati dan dikaji ulang.

\section{B. GAMBARAN UMUM LOKASI}

Kuala Jelai merupakan sebuah kelurahan di Kecamatan Jelai, Kabupaten Sukamara, Provinsi Kalimantan Tengah.
Jumlah penduduk Kuala Jelai 3.200 Jiwa dengan kepadatan 94,12 jiwa/km dan luas $34 \mathrm{~km}$. Secara geografis Kuala Jelai terletak pada $2^{\circ} 19^{\prime}$ sampai dengan $3^{\circ} 07^{\prime}$ Lintang Selatan (LS) dan $110^{\circ} 25^{\prime}$ sampai dengan $111^{\circ} 9^{\prime}$ Bujur Timur (BT), dengan batas-batas wilayah sebelah Utarayang berbatasan dengan Kecamatan Lamandau dan Kecamatan Bulik Kabupaten Lamandau, sebelah timur yang berbatasan dengan Kecamatan Kotawaringin Lama dan Kecamatan Arut Selatan Kabupaten Kotawaringin Barat, sebelah selatanyang berbatasan dengan Laut Jawa dan sebelah barat yang berbatasan dengan Kabupaten Ketapang Provinsi Kalimantan Barat.

Kepadatan penduduk Kuala Jelai masing cukup kecil dibandingkan daerah lain di Kalimantan Tengah. Pada tahun 2012 sebesar 12 jiwa per $/ \mathrm{km} 2$ dan meningkat dari tahun 2009 yang hanya sebesar 11.30 jiwa/km2. Kecamatan Jelai merupakan daerah dengan kepadatan penduduk terkecil yaitu 6 jiwa $/ \mathrm{km} 2$. Sedangkan Kecamatan Sukamara masih yang tertinggi di Kabupaten Sukamara dengan kepadatan penduduk $19 \mathrm{Jiwa} / \mathrm{km} 2$. Penduduk Kabupaten Sukamara berumur 10 tahun ke atas yang melek huruf berjumlah 34.709 jiwa atau 94,61 persen dari jumlah penduduk yang berusia 10 tahun keatas.

Kuala Jelai ini memiliki daerah tangkapan dengan luas areal kurang lebih 379.000 Ha, yang mencakup wilayah Kecamatan Sukamara, Kecamatan Jelai, dan Kecamatan Balai Riam. Sungai ini memiliki panjang $200 \mathrm{~km}$, kedalaman rata-rata 5 meter dan lebar rata-rata 100 meter. Sumber daya alam yang terdapat di Kabupaten Sukamara sebagian besar adalah hutan, bahan tambang, disamping itu juga mempunyai potensi sumberdaya laut, sungai, obyek wisata serta sumberdayalahan yang sesuai untuk dimanfaatkan bagi budi daya pertanian dan perkebunan serta peternakan. Sungai Kuala Jelai sekaligus menjadi perbatasan dengan Provinsi Kalimantan Barat dan juga merupakan alur sungai yang alamnya 
masih alami dan segar untuk dinikmati karena memiliki daya tarik tersendiri.

Kuala Jelai memiliki beberapa objek wisata yang cukup berpotensi dan sangat menarik untuk dikunjungi karena memiliki kekhasan tersendiri. Objek wisata yang dimiliki adalah Pantai anugerah. Pantai inilah yang sampai sekarang dijadikan sebagai tempat pelaksanaan tradisi syukuran laut. Masyarakat Kuala Jelai termasuk masyarakat yang sangat menghargai seni budaya, memiliki keragaman budaya yang multi etnis sehingga dapat memperkaya kesenian budaya setempat. Budayabudaya yang saat Pantun Seloka, Barongsai, Seni Kosidah, Tari Japen, Hadrah dan sebagainya.

\section{SEJARAH PERKEMBANGAN SYUKURAN LAUT}

Syukuran laut merupakan sebuah tradisi dari nenek moyang yang turuntemurun hingga sampai saat ini masih di lestarikan. Tradisi syukuran laut ini sudah ada semenjak tahun 2006 yang lalu. Berarti hampir 17 tahun lamanya tradisi ini dilestarikan. Awalnya yang mengembangkan tradisi ini adalah mbah wijanto dan sekarang beliau sudah wafat.Mengapa diadakan syukuran laut karena sebelumnya itu pernah terjadi bencana pada masyarakat sekitar. Dan dulunya pun tradisi syukuran laut ini tidak semegah dengan yang sekarang, mereka hanya melakukan dengan acara sederhana. Karena dulunya hanya orang-orang tertentu saja yang ikut dalam tradisi tersebut. Dan sekarang ini karena sudah ada perkembangan, maka Bapak Bupati memberikan kebijakan dan menghimbau agar setiap tahunnya masyarakat Kuala Jelai ikut andil dalam melaksanakan tradisi syukuran laut tersebut. Masyarakat Kuala Jelai saling bahu-membahu agar tradisi ini tidak punah dan terus dipertahankan.
Seiring dengan berkembangnya zaman tradisi syukuran laut di Kuala Jelai sudah banyak mengalami perubahan, dan pola pemikiran masyarakatnya sudah banyak yang berkembang, ini dikarenakan generasi muda di Kuala Jelai sudah mempunyai pendidikan yang tinggi terutama dalam bidang agama. Berkembangnya pola pemikiran dalam ilmu keagamaan sedikit banyak mempengaruhi cara pandang terhadap tradisi syukuran laut, yang notabennya dalam pelaksanan tradisi syukuran laut masih mempercayai hal gaib, mistis, dan sesaji yang diperuntukan kepada penguasa laut. Karena, upacara syukuran laut tidak bisa dinyatakan terbebas dan bersih dari unsur kesyirikan jika dalam pelaksanaannya dikaitkan dengan tujuan suguhan/sesajen sebagai penghambaan kepada roh-roh yang diyakini memiliki kekuatan ghaib dan sebagainya.

Mayoritas masyarakat di Kuala Jelai adalah nelayan dengan mata pencahariannnya adalah menangkap ikan dan lain sebagainya. Dulunya syukuran laut ini dikenal dengan pesta laut yang dimaksudkan sebagai ucapan syukur terhadap Tuhan Yang Maha Esa yang telah memberikan rezeki serta keselamatan terhadap para nelayan dan masyarakat sekitar. Masyarakat Kuala Jelai memiliki kearifan lokal salah satunya yaitu penghargaan terhadap laut dengan konsep berupa syukuran laut. Dengan demikian kearifan lokal juga perlu digali dan dipromosikan sehingga dapat menjadi pembelajaran bagi komunitas lain. Belajar dari kearifan lokal suatu masyarakat berguna bagi masyarakat lain sebab nilainilai kearifan lokal sudah pasti merupakan sesuatu yang sudah teruji oleh ruang dan waktu. Oleh karena itu tidak perlu diragukan lagi bahwa kearifan lokal dapat menjadi model dalam kehidupan masyarakat (Yusriadi, 2014:2).

Tradisi Syukuran Lautini juga dilakukan di daerah-daerah lain, daerah yang memiliki tradisi yang serupa dengan tradisi syukuran lautini yaitu, Madura, 
Banyuwangi, dan masih banyak daerah yang memiliki upacara semacam ini (Ayu, 2014:11).Dengan pemanfaatan tradisi syukuran laut ini pada masyarakat Kuala Jelai dijadikan sebagai supplement Sejarah Bahari diharapkan dapat meningkatkan pemahaman masyarakat terutama nelayan tentang pentingnya melestarikan tradisi yang berkaitan dengan laut. Selain itu, juga menumbuhkan kebanggaan sebagai seorang nelayan maupun masyarakat yang ada di Desa.

Syukuran laut (Sedekah laut) artinya pemberian yang didasarkan hendak mencari keridhaan Allah. Pemberian sedekah itu hendaknya dengan niat ikhlas karena Allah dan kepuasan hati untuk menolong sesama manusia, terutama orang yang hidup kekurangan.Sedekah menumbuhkan harta dan memberi keberkahan. Allah berfirman dalam Al-Qur'an Surah At-Taubah:75-76:

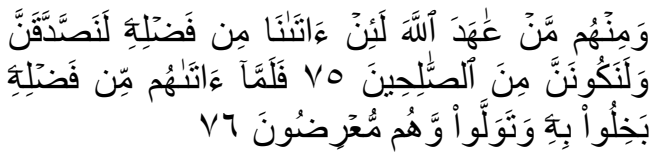

Artinya :

"Dan diantara mereka ada orang yang telah berikrar kepada Allah: "Sesungguhnya jika Allah memberikan sebahagian karunia-Nya kepada kami, pastilah kami akan bersedekah dan pastilah kami termasuk orang-orang yang saleh. Maka setelah Allah memberikan kepada mereka sebahagian dari karunia-Nya, mereka kikir dengan karunia itu, dan berpaling, dan mereka memanglah orang-orang yang selalu membelakangi (kebenaran)”. Q.s At-Taubah :75-76

Berdasarkan hasil wawancara dengan salah satu tokoh masyarakat yakni bapak Maulana bahwa hasil yang diperoleh dari laut selama ini sangat membantu untuk memenuhi kebutuhan sehari-hari, dan membiayai pendidikan keluarganya. Peran laut bagi kehidupan masyarakat Kuala Jelai sangat penting untuk membantu berlangsungnya kehidupan mereka, sehingga masyarakat mengadakan upacara syukuran laut sebagai bentuk rasa syukur kepada Allah yang telah memberikan berkah dan keselamatan kepada mereka ketika melaut.

Menurut mereka hasil yang di peroleh dari laut harus di syukuri lewat perantara laut juga. Syukuran laut ini merupakan salah satu cara yang paling tepat bagi nelayan di pesisir pantai untuk mensyukuri hasil dari laut dan nikmat yang diberikan oleh Allah SWT.Upacara syukuran laut bagi masyarakat Kuala Jelai merupakan simbol dari bentuk syukur atau rezeki yang diberikan Tuhan dari alam lautan, bentuk penghargaan terhadap laut.

Pada dasarnya syukuran laut tidak dapat di pisahkan dengan nelayan, dimana syukuran laut ini adalah bagian dari kehidupan masyarakat nelayan. Syukuran laut banyak juga di kenal dengan istilah sedekah laut, yang kesemuanya itu mempunyai tujuan yang sama, yaitu sebagai wujud rasa syukur serta sebagai permohonan agar mendapatkan berkah dan keselamatan serta pada tahun-tahun yang akan datang bisa mendapatkan hasil laut yang lebih banyak. Syukuran laut dilaksanakan oleh sebagian orang melayu termasuk masyarakat Kuala Jelai dan ini menjadi salah satu kearifan lokal yang dimiliki kabupaten Sukamara. Maksud dari kearifan lokal adalah nilai-nilai luhur yang masih berlaku dalam tata kehidupan masyarakat (Sismudjoto, 2015:4).

Dengan demikian pula Syukuran laut hendaknya dapat dijadikan sebagai ajang pembinaan tauhid dan wisata, sehingga bukan hanya bersifat kegiatan serimonial saja akan tetapi dapat membawa kemajuan dengan mengandalkan wisatanya. Salah satu upaya yang dapat dilakukan adalah dengan menjaga kelestarian ekosistem laut di wilayah pantai. Jadi tradisi syukuran laut ini bentuk rasa syukur para nelayan 
terhadap rezeki yang diberikan oleh Tuhan.

\section{PELAKSANAAN SYUKURAN LAUT}

TRADISI

Pelaksanaan tradisi syukuran laut di Kuala Jelai dimulai pada pagi hari sampai acara selesai.Adapun pelaksanaan syukuran laut ini dilokasikan ada dua tempat yakni di Pantai Anugerah dan dilaut. Dahulunya pun diadakan dengan tempat yang sama. Sehingga pantai tersebut sudah dijadikan sebagai tempat dari pelaksanaan tradisi syukuran laut itu sendiri. Persiapan yang dilakukan masyarakat nelayan pun tidak di lakukan secara dadakan. Jauh hari sebelum dilakukan syukuran laut para nelayan melakukan beberapa persiapan yang dibutuhkan untuk acara tersebut. Prosesi syukuran laut sudah dipersiapkan semaksimal mungkin pada hari dan tanggal yang telah ditentukan oleh panitia acara.

Sebagai bahan perbandingan bahwa tradisi syukuran laut ini tidak hanya ada pada masyarakat Kuala Jelai saja yang melaksanakan tradisi tersebut. Namun ditempat lain juga mereka sama melakukan prosesi tradisi syukuran laut. Seperti halnya di Wonokerto yang setiap tahunnya mereka bersama-sama melakukan acara syukuran laut. Tetapi ada sisi hal yang berbeda pada syukuran laut yang ada di Wonokerto. Perbedaannya adalah pada prosesi tradisi yang memang hal itu harus mereka lakukan. Mereka menggunakan kepala sapi yang dijadikan sebagai sesaji kemudian diarungkan ke laut dengan maksud agar masyarakat nelayan terhindar dari segala marabahaya sesuai dengan keyakinan warga setempat yang memang belum tersentuh Islamisasi. Sedangkan pada masyarakat Kuala Jelai tidak menggunakan hal seperti itu karena mereka tidak lagi meyakini dengan hal tersebut setelah masuk nilai-nilai Islam pada mereka.
Acara syukuran laut di Kuala Jelai tidak hanya dihadiri oleh para nelayan saja, tetapi di padati oleh masyarakat umum, bahkan dari pemerintahan kabupaten, kecamatan dan kepolisian pun ikut andil dalam memeriahkan syukuran laut tersebut.Adapun yang terlibat dalam tradisi syukuran laut adalah para pejabat Kabupaten Sukamara, Polres Kabupaten Sukamara, Camat Sukamara, Lurah Sukamara, Tokoh Ulama, Tokoh Masyarakat, Warga Sukamara, dan Pemuda dari anak-anak sampai remaja. Adapun prosesi saat melaksanakan tradisi syukuran laut yakini dengan diawali penyambutan Bapak Bupati dan Wakil Bupati Sukamara, kemudian dilanjutkan dengan pawai bersama dengan warga sekitar menuju lokasi (Panggung), setelah itu sambutan dari Bapak Bupati Sukamara, kemudian melakukan doa bersama yang dipimpin oleh Tokoh Ulama sebelum pergi ke laut.Doa yang dibacakan dalam tradisi tersebut adalah doa selamat yang tujuannya adalah meminta perlindungan dan keselamatan bagi para nelayan selama mereka melaut. Setibanya di kapal, semua warga masayarakat diperbolehkan ikut berpartisipasi dalam acara tahunan yaitu syukuran laut dengan menggunakan kapal untuk pawai bersama. Kapal yang sudah dihiasi dengan umbul-umbul maupun bendera menandakan bahwa masyarakat Kuala Jelai sangat antusias dan ikut berpartisipasi dalam acara syukuran laut.

Setibanya di laut dilakukan doa bersama terlebih dahulu agar puncak acara tersebut berjalan dengan lancar.Setelah berdoa, dilanjutkan menabur bunga kelaut sebanyak tiga kali oleh Bapak Bupati.Tujuan ditaburkan bunga adalah agar nelayan setetmpat dijauhkan dari segala bahaya dan dilancarkan rezekinya selama mereka melaut. Kemudian setelah menabur bunga, dilanjutkan makan tumpeng bersama di kapal dengan duduk saling berhadap-hadapan atau disebut dengan duduk berdampingan. Dikapal menggunakan tikar sebagai alas untuk 
mereka duduk. Tujuan dari makan tumpeng ini adalah untuk memupuk tali silaturahmi agar terjalin dengan baik. Kemudian setelah makan tumpeng bersama, semua kapal kembali ke lokasi acara yaitu di Pantai Anugerah dan diisi dengan hiburan sampai acara selesai.

Syukuran laut ini dihadiri oleh banyak artis lokal dan Ibu Kota agar menarik para wisatawan untuk berkunjung ke Kuala Jelai.Pada tahun 2006 sampai sekarang tradisi tersebut selelau dihadiri artis Ibu Kota seperti Gita KDI, Yuli KDI, DANANG KDI dan lain sebagainya. Dan banyak juga dihadiri artis lokal yakni dari Sukamara yang bernama Karmila dan lain-lain. Dengan meriahnya perayaan syukuran laut tentu saja tidak hanya menarik masyarakat yang ingin menyaksikan ritual syukuran laut, tetapi juga akan menarik wisatawan luar, serta menarik minat masyarakat untuk memanfaatkan momen ini sebagai media mencari keuntungan ekonomi. Mengenai potensi ekonomi dalam penyelenggaraan akan sangat menarik perhatian masyarakat, khususnya dalam kepanitiaan. Acara yang cukup besar juga akan memerlukan tenaga dan pembiayaan yang besar pula. Potensi ini juga pasti akan menarik perhatian setiap individu yang masuk dalam jajaran kepanitiaan.Bapak Bupati H.Ahmad Dirman mengatakan bahwa melalui acara ini agar terus dipertahankan dan ditingkatkan. Tidak saja menjadi acara rutin, tetapi juga bisa sebagai ajang promosi potensi kepariwisataan dan kelautan. Kecamatan Jelai memiliki daerah yang berpotensi dan dikembangkan agar dapat menarik wisatawan untuk datang.

\section{E. MEDIA DAN SIMBOL DALAM TRADISI SYUKURAN LAUT}

Manusia membentuk kebudayaan dengan mengkomunikasikan sesuatu hal melalui simbol-simbol. Lambang atau simbol adalah suatu yang digunakan untuk menunjuk sesuatu lainnya, berdasarkan kesepakatan sekelompok orang. Simbol meliputi kata-kata (pesan verbal), perilaku non verbal, dan objek yang maknanya disepakati bersama (Mulyana, 2010:92). Tradisi syukuran laut ini mempunyai makna lebih dari itu. Upacara tradisional syukuran laut itu sudah menjadi salah satu bagian yang sudah menyatu dengan masyarakat yang tidak akan mampu untuk dipisahkan dari budaya melayu yang menyiratkan simbol penjagaan terhadap kelestarian yang khas bagi masyarakat ang sebagian besar berprofesi sebagai nelayan (Budiono, 2001:25).

Pemaknaan simbol tersebut adalah hasil dari proses interaksi manusia dan disetujui bersama oleh orang-orang yang terlibat di dalamnya. Simbol dapat dimanifestasikan melalui sebuah benda, gambar maupun lambang. Jadi, setiap benda yang ada di sekitar kita memiliki kapasitas untuk menyampaikan pesan atau maksud yang ingin disampaikan oleh orang yang membuat simbol (Ilaihi, 2012:46).Tradisi syukuran laut yang sering dilakukan masyarakat nelayan merupakan salah satu kebudayaan di Indonesia yang masih dipertahankan sampai sekarang.Kemampuan manusia untuk berkomunikasi dengan menciptakan bahasa simbolik sebagai pemaknaan terhadap nilai-nilai maupun suatu hal lainnya yang akhirnya membentuk suatu kebudayaan.

Dalam syukuran laut ini menghadirkan kembali suatu proses atau peristiwa yang pernah dilakukan dahulu oleh leluhur. Maka usaha serupa pun akan terjadi lagi, karena hadirnya prosesi syukuran laut di masyarakat nelayan telah lama dan menjadi bagian didalam kehidupannya. Simbol-simbol yang ada didalam prosesi ini dapat berubah namun fungsinya akan tetap sama. Kegiatan tradisi Syukuran laut hingga kini masih berlangsung dan dikerjakan secara berkala (Ramantika, 2014:205)

Tradisi Syukuran laut diselenggarakan secara berkala dan dijadikan hari yang istimewa sebagai 
ungkapan rasa syukur dikarenakan terhindar dari berbagai gangguan atau bencana alam.Tradisi ini menjadi salah satu ritual yang dilakukan oleh masyarakat pesisir pantai, dan kebanyakan ritual yang dilakukan oleh masyarakat nelayan terutama di Kabupaten Sukamara. Di setiap daerah, acara tardisi syukuran laut memiliki kekhasan masing-masing, mulai dari penyebutan atau penamaan ritual yang berbeda-beda, hingga proses ritual yang mempunya tata cara yang berbeda pula.

Dengan meriahnya perayaan sedekah laut tentu saja tidak hanya menarik masyarakat yang ingin menyaksikan ritual sedekah laut, juga akan menarik wisatawan luar, serta menarik minat masyarakat untuk memanfaatkan momen sedekah laut untuk mencari keuntungan ekonomi. Adapun penyelenggaraan Syukuran laut ini banyak melibatkan berbagai pihak dimana pihakpihak ini akan memanfaatkan acara sedekah laut sebagai nilai yang dapat di tukar dengan keuntungan materi, dimana penyelenggara Syukuran Laut dapat menjadi nilai jual yang tinggi.Berdasarkan hasil wawancara dengan tokoh masyarakat, didapati bahwa diperlukan peralatan yang digunakan pada tradisi syukuran laut seperti kapal, tikar, bunga, dan lain-lain.

Sedangkan makna simbol dari proses pelaksanaan tradisi syukuran laut ini adalah yang pertama dengan melakukan pawai bersama di atas kapal. Maknanya menjalin kebersamaan serta kekeluargaan yang damai dan sejahtera. Kapal dihiasi dengan umbul-umbul dan bendera yang memberikan makna partisipasi masyarakat dalam mengikuti pelaksanaan tradisi syukuran laut.

Kemudian dilanjutkan dengan siraman air ke laut. Hal tersebut memberikan makna sebagai tanda berbagi keceriaan setelah setahun penuh mendapatkan rejeki dari hasil melaut. Setelah itu dilanjutkan penaburan Bunga ke laut sebanyak tiga kali. Maknanya adalah agar masyarakat Kuala Jelai khususnya bagi nelayan agar dijauhkan dari segala marabahaya. Bunga yang ditaburkan bewarna-warni dengan maksud untuk menyatukan berbagai macam suku, budaya, agama maupun ras.

Makna-makna simbolik yang terkandung dalam bagian-bagian prosesi upacara adat syukuran laut di Kabupaten Sukamara bahwa upacara adat syukuran laut merupakan suatu tradisi yang di bentuk oleh masyarakat setempat dengan mengaplikasikan suatu nilai-nilai kebaikan pada setiap runtutan prosesinya. Suatu nilai yang di dalamnya mengungkapkan tentang rasa syukur masyarakat Kuala Jelai kepada sang pencipta atas kenikmatan yang sudah diberikan. Selain itu upacara syukuran laut di Sukamara juga suatu bentuk penghormatan kepada sejarah, dimana keyakinan mereka kepada penjaga laut atau dewa dewi laut pada zaman dahulu, berubah menjadi penghambaan dan rasa syukur mereka kepada sang pencipta setelah adanya interaksi dengan nilai-nilai Islam sehingga syukuran dilakukan dengan doa Islami. Dengan ungkapan rasa syukur dan rasa hormat tersebut, terbentuk suatu simbol dengan adanya upacara adat yang diberi nama dengan syukuran laut (sedekah laut).

\section{F. NILAI-NILAI DALAM TRADISI SYUKURAN LAUT}

Tradisi Syukuran Laut merupakan daya tarik wisata dengan nilai budaya yang sangat tinggi pada masyarakat Kuala Jelai. Tingginya nilai budaya tersebut, terbukti telah ada dan turun temurun sampai pada generasi saat ini, sehingga menjadi bukti sejarah kebudayaan asli Indonesia. Tradisi ini berperan penting sebagai pemersatu anggota masyarakat yang satu dengan masyarakat yang lain. Keberadaan tradisi syukuran laut ini berhubungan timbal balik dengan sitem kepercayaan (religi) masyarakat pendukungnya. Masyarakat Sukamara 
mayoritas beragama Islam dan masih mempercayai dengan keberadaan roh-roh penunggu laut (Syarifuddin, 2015:100),sehingga perlu diluruskan supaya tidak bercampur dengan kesyirikan, dan di sinilah urgensinya pembinaan tauhid kepada masyarakat muslim Sukamara dalam pelaksanaan syukuran laut, sehingga mereka dapat mencapai tujuan yang di maksud sebagai bentuk rasa syukur kepada sang pencipta dan penguasa alam semesta.

Tradisi syukuran di Kuala Jelai mempunyai manfaat yang sangat besar terutama bagi nelayan, usaha masyarakat, sikap gotong-royong, mempererat tali persaudaraan dan kumpul rukun sesama warga masyarakat dan sarana hiburan bagi masyarakat setempat. Adapun yang dimaksud dengan nilai-nilai dalam budaya adalah suatu rangkaian dari konsepsikonsepsi abstrak yang hidup dalam pikiran sebagian besar dari warga suatu masyarakat, mengenai kehidupan yang harus dianggap penting dan berharga dalam hidup. Nilai budaya ini berfungsi sebagai suatu sistem tata kelakuan dan pedoman tingkah laku manusia seperti hukum adat, aturan sopan santun, adat istiadat dan lain sebagainya sehingga dalam kehidupan sehari-hari akan mempengaruhi tingkah laku dan perbuatan serta sikap manusia dalam hidup bermasyarakat (Purwahida, 2008:21).

Dengan adanya tradisi syukuran laut masyarakat Kuala Jelai merasa sebagai satu keluarga besar, mereka dapat membina kerukunan antar sesama warga masyarakat. Apabila kerukunan itu dapat tercapai maka mereka dapat bersatu dalam membangun daerahnya sehingga mereka mengejar ketinggalan dan meninggalkan keterbelakangan mereka.

Syukuran laut dapat menanamkan jiwa sosial gotong royong pada masyarakat setempat. Kemudian nilai keagamaan. Proses kegiatan syukuran laut ini merupakan ritual yang di dalamnya terjadi tingkah laku religius aktif, ucapan doa-doa tertentu diyakini mempunyai kekuatan yang dapat menghasilkan energi baru bagi aktivitas masyarakat nelayan. Dan yang terakhir adalah nilai pendidikan. Secara tidak disadari bahwa tradisi syukuran laut ternyata mempunyai nilai pendidikan, pembelajaran melalui pengalaman langsung lewat tradisi syukuran laut yang setiap tahunnya selalu di selenggarakan. Beberapa kegiatan yang mendukung acara syukuran laut termasuk yang terdiri dari larungan, dan hiburan yang ternyata mempunyai nilai-nilai yang sangat bagus untuk pembentukan karakter masyarakat Kuala Jelai dengan menciptakan kebersamaan, gotongroyong, rukun, dan saling menghargai kepada sesama.

Dengan demikian Syukuran laut dapat menjadi sebuah proses pendidikan bagi masyarakat Kuala Jelai yaitu dengan meningkatkan nilai-nilai yang menunjang pembentukan karakter. Dengan terbentuknya karakter semacam itu, maka nilai-nilai budaya luhur tetap terpelihara dan terjaga dengan baik.

\section{G. KESIMPULAN}

Berdasarkan pemaparan pada bagian sebelumnya dapat disimpulkan bahwa syukuran laut ini merupakan salah satu kearifan lokal yang dimiliki kabupaten Sukamara. Maksud dari tujuan Syukuran Laut ini yaitu memohon pada Tuhan Yang Maha Esa agar para nelayan dianugerahi hasil yang laut melimpah pada tahun yang akan datang dan dihindarkan pula dari marabahaya selama melaut. Syukuran laut hendaknya dapat dijadikan ajang wisata, sehingga bukan hanya bersifat kegiatan serimonial saja akan tetapi dapat membawa kemajuan dengan mengandalkan wisatanya. Salah satu upaya yang dapat dilakukan adalah dengan menjaga kelestarian ekosistem laut di wilayah pantai.

Peran laut bagi kehidupan masyarakat Kuala Jelai sangat penting untuk membantu berlangsungnya kehidupan mereka, sehingga masyarakat mengadakan upacara syukuran laut 
sebagai bentuk rasa syukur kepada Allah yang telah memberikan berkah dan keselamatan kepada mereka ketika melaut. Semua warga masayarakat diperbolehkan ikut berpartisipasi dalam acara tahunan yaitu syukuran laut dengan menggunakan kapal untuk pawai bersama. Kapal yang sudah dihiasi dengan umbulumbul maupun bendera dengan menandakan bahwa masyarakat Kuala Jelai sangat antusias dan ikut berpartisipasi dalam acara syukuran laut. Adapun makna-makna simbolik yang terkandung dalam bagian-bagian prosesi upacara adat syukuran laut di Kabupaten Sukamara berupa upacara adat syukuran laut merupakan suatu tradisi yang di bentuk oleh masyarakat setempat dengan mengaplikasikan suatu nilai-nilai kebaikan pada setiap runtutan prosesinya. Suatu nilai yang di dalamnya mengungkapkan tentang rasa syukur masyarakat Kuala Jelai kepada sang pencipta atas kenikmatan yang sudah diberikan.

Selain itu, upacara syukuran laut di Kuala Jelai juga merupakan suatu bentuk penghormatan kepada sejarah dimana keyakinan lama oleh masyarakat setempat yang kemudian berevolusi menjadi sebuah budaya/adat yang selaras dengan nilainilai agama sebagai bentuk proses Islamisasi. Dalam proses pelaksanaan tradisi syukuran laut tersebut terdapat beberapa nilai yang terkandung di dalamnya yaitu nilai keagamaan, kemasyarakatan dan pendidikan.Dengan adanya pelaksanaan syukuran laut ini, rasa kebersamaan dan kekompakan masyarakat Kuala Jelai dapat lebih ditingkatkan guna menunjang suksesnya program pembangunan dalam berbagai bidang, khususnya bidang kelautan dan perikanan serta pariwisata. Di antaranya, mengembangkan potensi pesisir dan lautan untuk berbagai kegiatan perikanan baik penangkapan ikan maupun kegiatan budidaya yang dapat memberikan kontribusi besar dalam peningkatan pertumbuhan ekonomi dan kesejahteraan masyarakat nelayan.

\section{DAFTAR PUSTAKA}

Asmito. (2010). Tradisi sedekah laut pada masyarakat Jawa : Tinjauan sosial budaya: Ibda. Vol 9 (1) : 24-35.

Ayu. (2014). Pemertahanan Tradisi Budaya Petik Laut Oleh Nelayan Hindu dan Bali :Histori. Vol 11 (2) : 1-12.

Bawani. (2015). Upcara Dalam Tradisi sedekat laut dalam sudut pandang budaya kearifan lokal : Kebudayaan Islam. Vol 13 (1) : 22-30.

Budiyono. 2001. Simbolisme Dalam Budaya Jawa. Yogyakarta. Hanindita Grahawidia.

Ilaihi. (2012). Simbol Keislaman pada Tradisi Rokat Tase dalam Komunikasi pada Masyarakat Desa Nepa :Indo-Islamika. Vol 2 (1) : 45-58.

Koentjaraningrat. (1985). Sejarah Teori Antropologi. Jakarta : Balai Pustaka.

Purwahida. (2008). Bahasa dalam upacara larung, sedekah laut di laut Bonang: Pelita. Vol 3 (1) : 2128

Rasyidin. (2009). Strategi Penyebaran Tradisi Islam pada Masyarakat Jawa : Ibda. Vol 10 (2) : 217221.

Ramantika. (2014). Perubahan ruang pada tradisi sedekah laut : elHarakah. Vol 16 (2) : 203-215.

Syarifuddin. (2015). Daya Tarik Wisata Upacara Tradisional Hajat Laut Sebagai Nilai Budaya Masyarakat Batu Karas :Manajemen Resort \& Leisure. Vol 12 (1) : 100-110.

Sismudjito. 2015. Eksistensi masyarakat pada wilayah pesisir pantai :Kebudayaan. Vol 12 (1) :1-7.

Widati. (2011). Tradisi Sedekah laut di Wonokerto Kabupaten Pekalongan 
: Kajian Perbahan bentuk dan fungsi :Ibda. Vol 1 (2) : 142-148.

Wiranata. (2011). Antropologi Budaya. Bandung: PT. Citra Aditya Bakti.

Wawancara dengan Bapak Maulana (umur 45 tahun), Tokoh Masyarakat, pada hari Jum'at tanggal 12 Juli 2018.
Yusriadi. 2014. Budaya dan Kearifan Lokal. Pontianak : STAIN Pontianak.

Prasojo, Z. H. 2017. Religious and cultural exsistenses withn the communities of Upper Kapuas Riverside of west Kalimantan :Al Albab. Vol 6 (2) : 197-21. 